\title{
Peningkatan Kualitas Laporan Keuangan Dengan Software MYOB Accounting Versi 16 Sri Murni ${ }^{1}$, Noraeni ${ }^{2}$
}

\begin{tabular}{ll}
\hline Info Artikel \\
\hline \\
Diterima Desember 10, 2020 \\
Revisi Januari 10, 2020 \\
Terbit $\quad$ Maret 31, 2020 \\
\hline
\end{tabular}

Keywords:

Implementation of Accounting Applications

MYOB

Accounting

\begin{abstract}
Computer technology has helped many people in overcoming problems that occur including in the fields of business and accounting. The object of research is CV. Malianury Graffiti which is a printing service company. The company records and presents reports using the Microsoft Excel application. The final report is only in the form of sales reports and financial transaction records. Thus this company performs manual calculations to determine the company's profit / loss. The purpose of this study is to provide solutions to problems that occur and compare the conventional recording with recording using accounting software, MYOB Premier V.16 on CV. Malianury Graffiti. The research method used in the form of data collection methods are observation, interviews and literature study. It is hoped that this research can facilitate the company in processing transactions into financial statements, improving the results of financial statements, useful for related parties in analyzing financial statements and in decision making.
\end{abstract}

\section{Identitas Penulis:}

Sri Murni ${ }^{1}$, Noraeni ${ }^{2}$

Universitas Bina Sarana Informatika Program Studi Sistem Informasi Akuntansi Kampus Pontianak

Jalan Abdurrahman Saleh no. 18 A Pontianak

Email: $\underline{\text { Sri.six@ @si.ac.id }}{ }^{1}$, noraeni@gmail.com ${ }^{2}$

\section{PENDAHULUAN}

Teknologi komputer telah banyak membantu manusia dalam mengatasi permasalahan yang terjadi termasuk dalam bidang bisnis dan akuntansi. Dengan didukung oleh Teknologi Informasi dan Komputer, pencatatan transaksi bisnis yang dahulu dilakukan secara manual, yang menggunakan buku dan kertas telah diganti dengan pencatatan menggunakan media komputer [2].

Didukung dengan pengetahuan IT (Information Technology), maka bidang akuntansi dan teknologi informasi dapat menciptakan berbagai macam software akuntansi salah satunya adalah aplikasi program Myob Premier V.16, diera teknologi yang sangat berkembang ini, aplikasi program Myob Premier V.16 sangat di perlukan untuk mengetahui kerugian dan keuntungan dalam keuangan perusahaan [1].

Myob Accounting Software adalah program akuntansi yang didesain untuk memenuhi kebutuhan penyediaan informasi akuntansi, sekaligus sebagai alat pengolah laporan keuangan [3].

CV. Malianury Grafiti Sungai Raya Dalam merupakan perusahaan jasa yang bergerak di bidang digital printing, perusahaan ini melayani pemesanan produk percetakan seperti pemesanan brosur, spanduk, id card, sablon, undangan, kalender, kartu nama, cetak buku, majalah, nota dll. Saat ini CV. Malianury Grafiti, dalam pencatatan dan ppengolahan transaksi sudah menggunakan komputer hanya saja pencatatan transaksi dan pembuatan laporan keuangan masih menggunakan cara sederhana dengan menggunakan Microsoft Excel. Laporan setiap bulan dibuat dengan mengisi data transaksi yang dihasilkan dari nota-nota transaksi ke dalam Microsoft Excel. Laporan akhir hanya berbentuk rekapan transaksi, dan laporan penjualan. Perusahaan belum menerapkan pencatatan transaksi keuangan yang sebenarnya dan tentunya jauh dari Standar Akuntansi Keuangan (SAK). Cara ini juga membutuhkan waktu yang lama, memungkinkan terjadinya kesalahan pencatatan, bentuk pelaporan tidak teratur dan bagi pihak terkait terutama pemilik perusahaan sulit membaca kondisi keuangan perusahaan. 
Dengan adanya aplikasi keuangan seperti MYOB Premier akan mempermudah, mempercepat pembuatan laporan dan tentunya memenuhi kriteria Standar Akuntansi Keuangan, dan kesalahan dalam proses pembuatan dan penyusunan laporan dapat diminimalisir. Aplikasi Akuntasi Myob Premier V.16 merupakan Software yang cukup handal di bidang accounting dan dapat menjadi solusi yang baik untuk memecahkan permasalahan yang terjadi di CV. Malianury Grafiti Sungai Raya Dalam.

\section{METODE PENGUMPULAN DATA}

1. Observasi

Pengamatan dilakukan dengan datang dan mengamati cara kerja sistem berjalan pada objek penelitian dengan mengamati hal-hal yang terkait dengan sistem pencatatan transaksi keuangan, mulai dari mengamati bukti transaksi, pencatatan pada Microsoft Excel, dan bentuk pelaporan.

2. Wawancara

Wawancara dilakukan untuk menanyakan hal-hal yang berkaitan dengan cara atau metode pencattan transaksi keuangan secara langsung kepada pihak terkait. Wawancara menghasilkan bagaimana tahapan pencatatan transaksi sehingga menghasilkan laporan akhir.

3. Studi Pustaka

Studi Pustaka dilakukan dengan cara mengumpulkan literatur yang diperoleh dari buku, internet, jurnal ilmiah maupun artikel sebagai bahan acuan dan referensi yang berkaitan dengan penelitian yang akan dibahas.

\section{HASIL}

Hasil penelitian dimulai dengan memaparkan tahapan hasil analisa pada sistem berjalan. Dipaparkan dalam bentuk apa adanya dan pada tahapan tertentu diolah untuk memudahkan peneliti dalam menyajikan hasil penelitian sehingga pembaca dapat dengan mudah memahami pembahasan. Tahapan penelitian dimulai dengan memaparkan tinjuan kasus secara rinci, pencatatan transaksi pada sistem yang sedang berjalan dan kemudian diimplementasikan dalam software akuntansi yaitu MYOB Premier Versi 16. Periode transaksi yang diambil sebagai sample penelitian adalah bulan Januari 2018.

\subsection{Tinjauan Kasus Penelitian}

CV. Malianury Grafiti Sungai Raya adalah perusahaan jasa yang bergerak di bidang digital printing. Periode laporan selama 1 bulan. Pada akhir bulan, dilakukan pencatatan transaksi pada Microsoft Excel dari nota-nota transaksi. Dalam pencatatan dan pengelolaan setiap transaksi masih menggunakan cara sederhana dengan menggunakan Program Microsoft Excel sebagai media pencatatan. Laporan tiap bulan dibuat dengan mengisi data transaksi yang dihasilkan dari nota-nota transaksi ke dalam Microsoft Excel. Laporan akhir berupa penjualan bukan laporan keuangan. Dengan demikian perusahaan tidak membuat laporan keuangan yang sesuai dengan Standar Akuntansi Keuangan (SAK). Selain itu pencatatan yang dilakukan menyebabkankan sering terjadinya kesalahan dalam pengolahan data dan membutuhkan lebih banyak waktu dalam pengerjaannya sehingga memperlambat informasi yang dibutuhkan.

\subsection{Hasil Pencatatan Akuntansi Sistem Berjalan}

\section{Daftar Akun}

Perusahaan tidak memiliki standar untuk daftar akun, berikut daftar akun yang diperoleh berdasarkan hasil analisa dari setiap transaksi yang terjadi. 


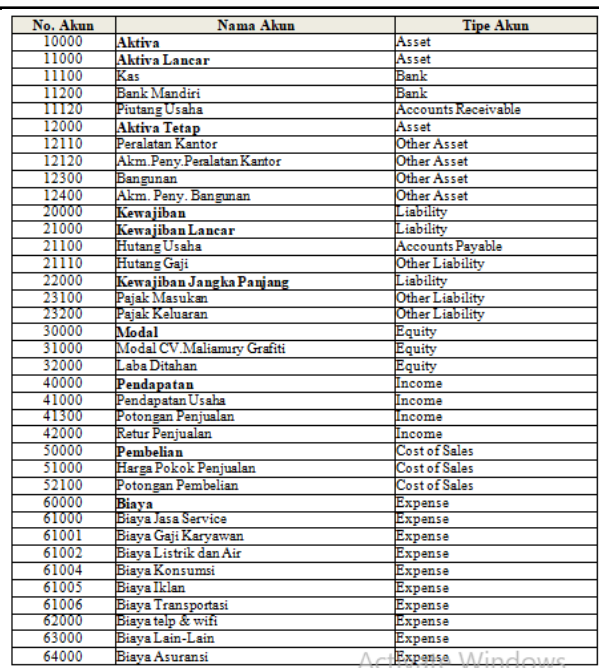

Sumber : Transaksi pada CV. Malianury Grafiti

Gambar 1. Daftar Akun

\section{Saldo Awal Akun}

Untuk memudahkan penyajian dan proses implementasi ke dalam aplikasi MYOB Premier Versi 16, transaksi pada periode sebelumnya perlu diolah laporan keuangannya sehingga menghasilkan saldo awal untuk periode selanjutnya.

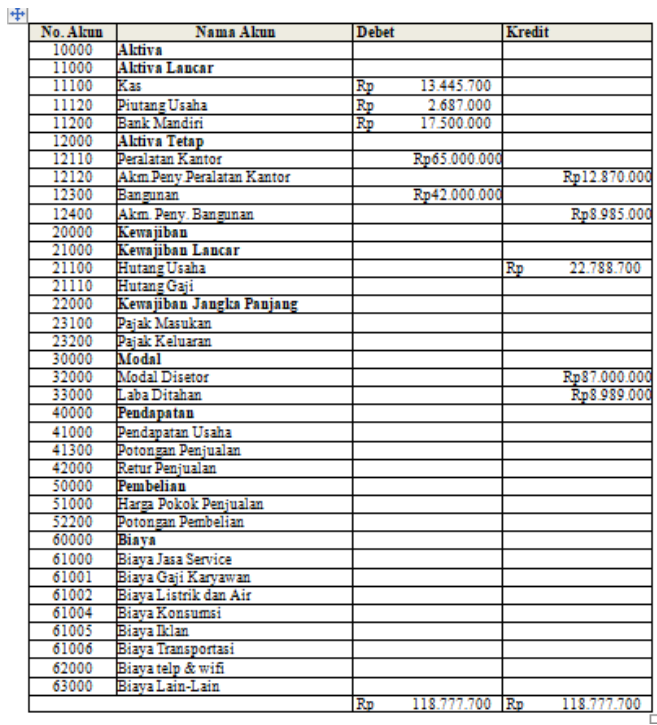

Sumber : CV. Malianury Grafiti

Gambar 2. Saldo Awal CV. Malianury Grafiti

\section{Pencatatan Piutang dan Hutang}

Sumber : CV. Malianury Grafity

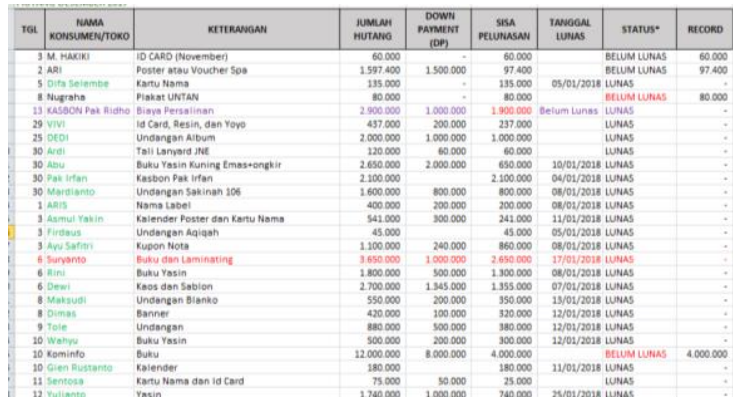

Gambar 3. Pencatatan Piutang 


\begin{tabular}{|c|c|c|c|c|c|c|c|c|}
\hline TGL & $\begin{array}{c}\text { NAMA } \\
\text { KONSUMEN/TOKO }\end{array}$ & KETERANGAN & $\begin{array}{l}\text { JUMLAH } \\
\text { HUTANG }\end{array}$ & $\begin{array}{c}\text { DOWN } \\
\text { PAYMENT } \\
\text { (DP) }\end{array}$ & $\begin{array}{c}\text { SISA } \\
\text { PEIUNASAN }\end{array}$ & $\begin{array}{l}\text { TANGGAL } \\
\text { LUNAS }\end{array}$ & STATUS* & RECORD \\
\hline & ISAHA MANDIRI & Beli Bahan Bangunan & \multicolumn{3}{|l|}{3.659 .000} & \multicolumn{3}{|c|}{ 20/01/2018 LUNAS } \\
\hline & CV. Irama Vision & Pembelian Bahan & 7.818 .000 & & 7.818 .000 & & BELUM LUNAS & 7.818 .000 \\
\hline & Dx Printing & Hutang Dx Printing & \multicolumn{3}{|l|}{2.465 .000} & \multicolumn{3}{|c|}{ 23/01/2018 LUNAS } \\
\hline & ASTRAGRAPHIA & Hutang Klik Mesin Januari 2018 & 16.570 .700 & & 16.570 .700 & & BELUM LUNAS & 16.570 .700 \\
\hline
\end{tabular}

Sumber : CV. Malianury Grafity

Gambar 4. Pencatatan Hutang

\section{Pencatatan Transaksi}

Sumber : CV. Malianury Grafity

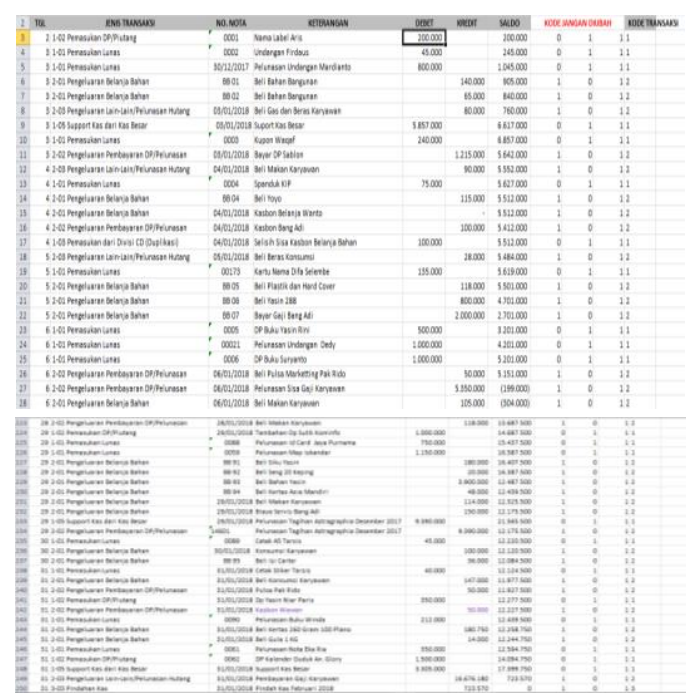

Gambar 5. Pencatatan Transaksi

\section{Laporan Penjualan}

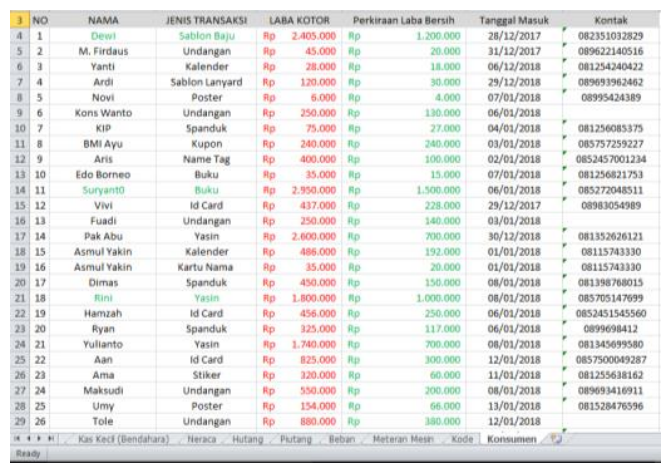

Sumber : CV. Malianury Grafity

Gambar 6. Laporan Penjualan

\subsection{Hasil Pencatatan dengan MYOB Premier Versi 16}

1. Penambahan Akun 


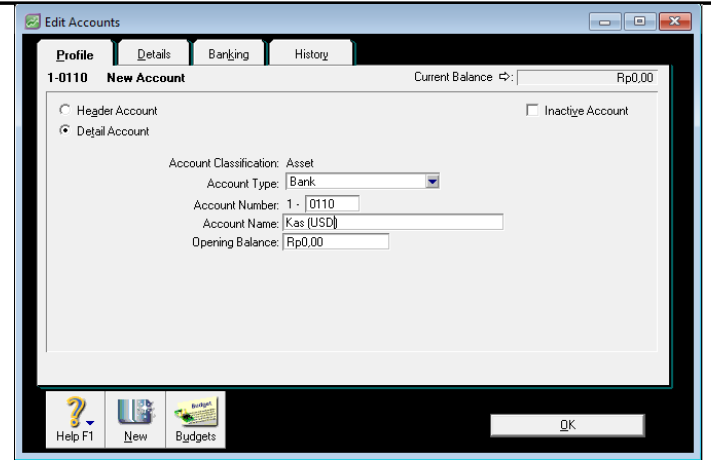

Sumber : Hasil Implementasi dengan MYOB Premier V.16

\section{Saldo Awal Akun}

Gambar 7. Tambah Akun

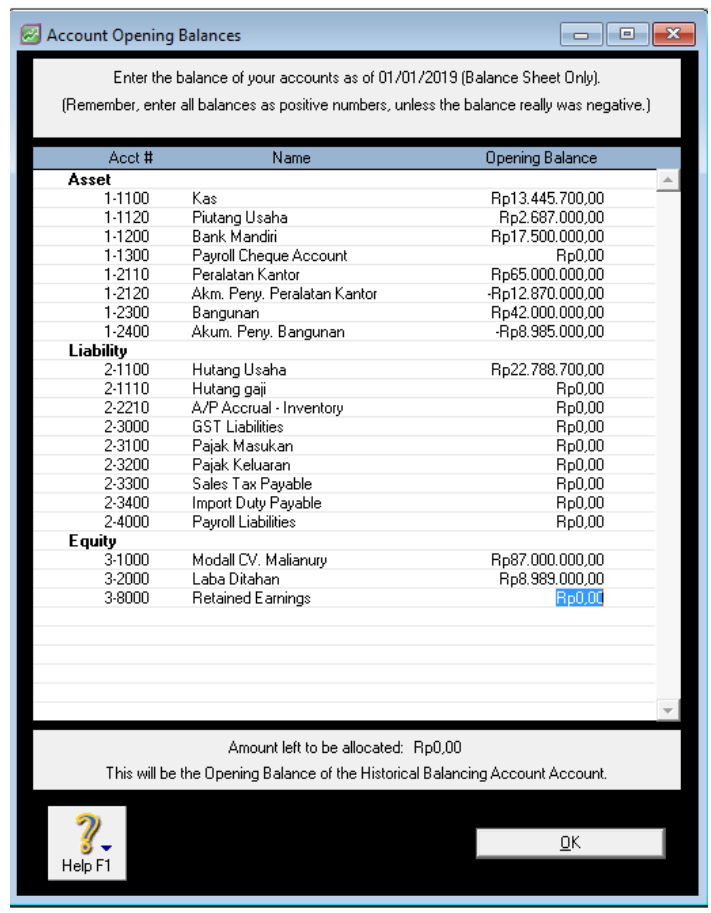

Sumber : Hasil Implementasi dengan MYOB Premier V.16

Gambar 8. Saldo Awal Akun

\section{Saldo Awal Hutang}

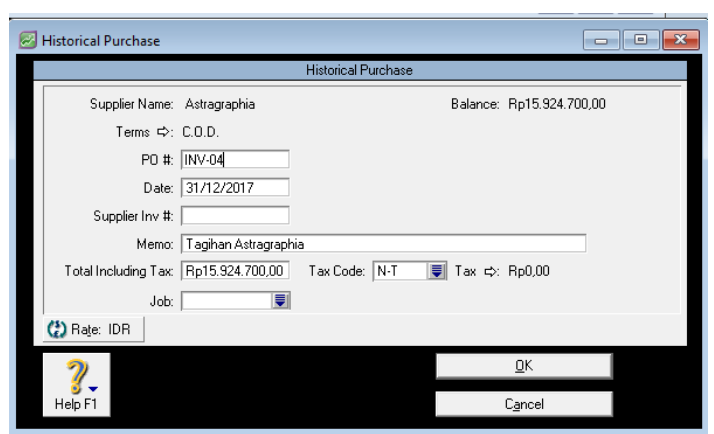

Sumber : Hasil Implementasi dengan MYOB Premier V.16

Gambar 9. Jendela Pengisian Saldo Awal Hutang 


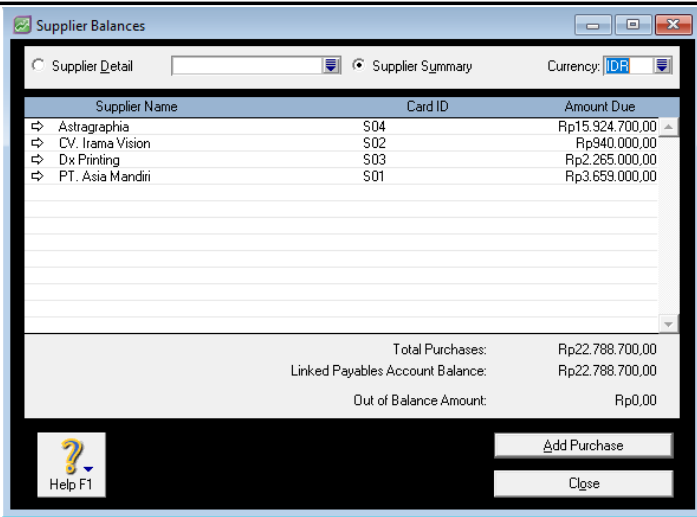

Sumber : Hasil Implementasi dengan MYOB Premier V.16

Gambar 10. Saldo Awal Hutang

\section{Saldo Awal Piutang}

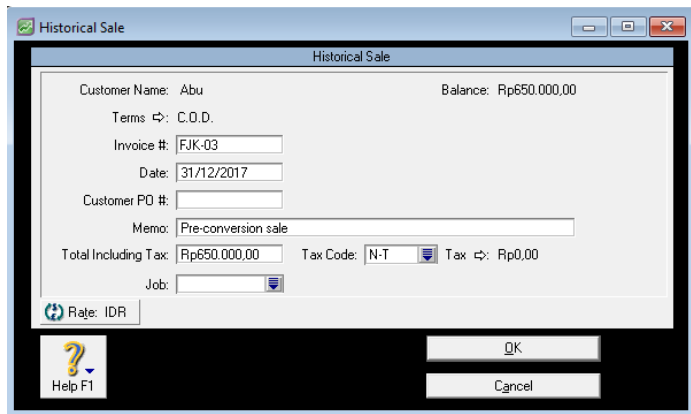

Sumber : Hasil Implementasi dengan MYOB Premier V.16

Gambar 11. Jendela Saldo Awal Piutang

\section{Laporan Penjualan}

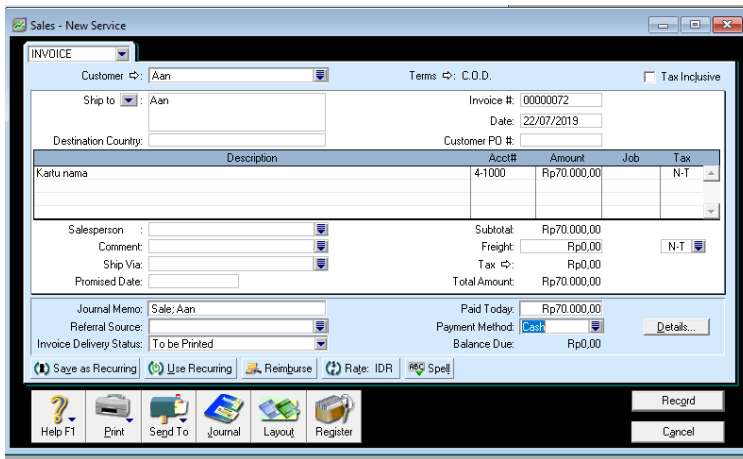

Sumber : Hasil Implementasi dengan MYOB Premier V.16

Gambar 12. Input Transaksi Penjualan 


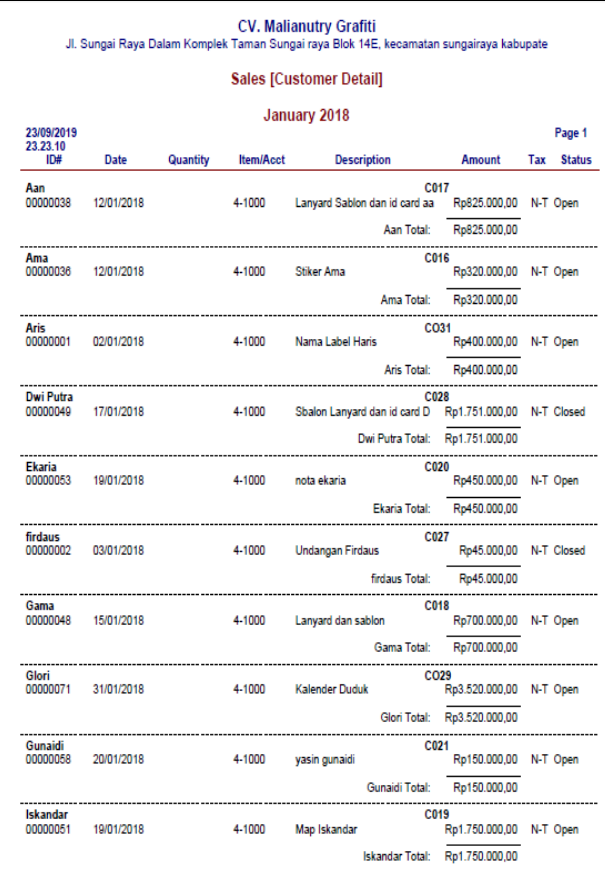

Sumber : Hasil Implementasi dengan MYOB Premier V.16

Gambar 13. Laporan Penjualan

\section{Neraca Saldo}

CV. Malianutry Grafiti

JI. Sungai Raya Dalam Komplek Taman Sungai raya Blok 14E, Kecamatan sungairaya kabupa

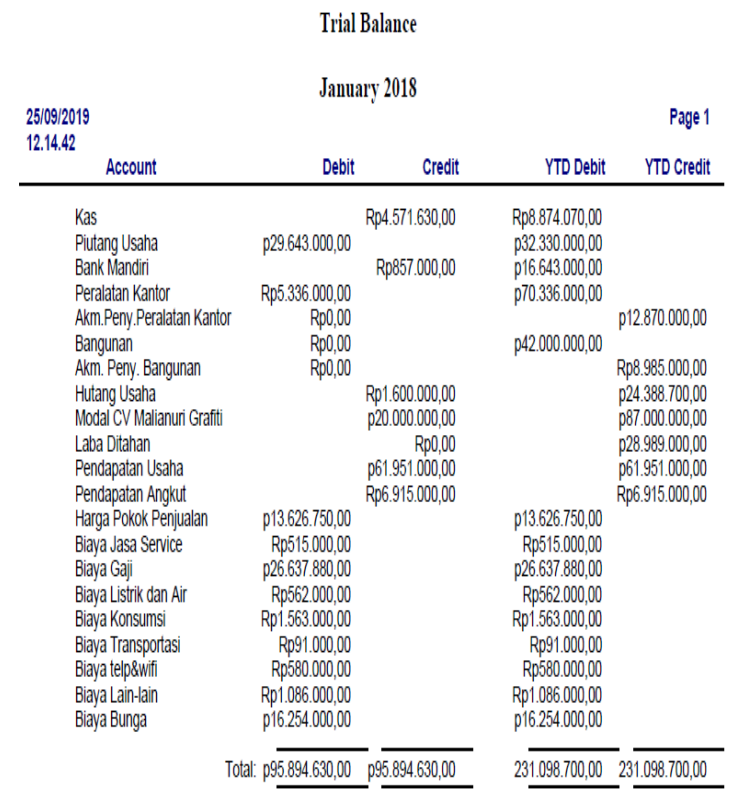

Sumber : Hasil Implementasi dengan MYOB Premier V.16

Gambar 14. Neraca Saldo

\section{Laporan Laba/Rugi}


CV. Malianutry Grafiti

Jl. Sungai Raya Dalam Komplek Taman Sungai raya Blok 14E, kecamatan sungaira

Statement of Comprehensive Income

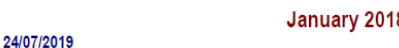

$24 / 07 / 2019$

January 2018

Penjualan

Pendapatan Usaha

Tal Penjua

Rp61.951.000,00
$\operatorname{Rp} 6.915 .000,00$

Pembelian
Harga Pokok Penjualan

Total Pembelian

$\mathrm{Rp68.866.000,00}$

Gross Profit

Rp13.626.750,00

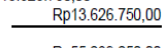

Biaya

Biaya Listrik dan A

Biaya Konsumsi

Biaya telp\&w

Bayaa Lain-lain

total Biaya

Operating Profit

$\mathrm{Rp55.239.250,00}$

Pendapatan Lain-La

Laba Rugi
Total Pendapatan Lain-Lai

Biaya Lain-Lain

Total Biaya Lain-Lain

Rp515.000,00

Rp26.637.880,00

Rp562.000,00

Rp $1.563 .000,00$
Rp91.000,00

Rp580.000,00

Rp1.086.000,00

Rp31.034.880,00

Rp24.204.370,00

Net Profit / (Loss)

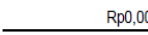

Rp16.254.000,00

$\mathrm{Rp} 16.254 .000,00$

Sumber : Hasil Implementasi dengan MYOB Premier V.16

Rp $7.950 .370,00$

Gambar 15. Laporan Laba Rugi

\section{Laporan Perubahan Modal}

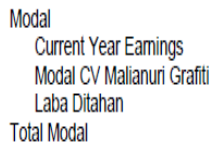

Sumber : Hasil Implementasi dengan MYOB Premier V.16

Gambar 16. Laporan Perubahan Modal

\section{Neraca}

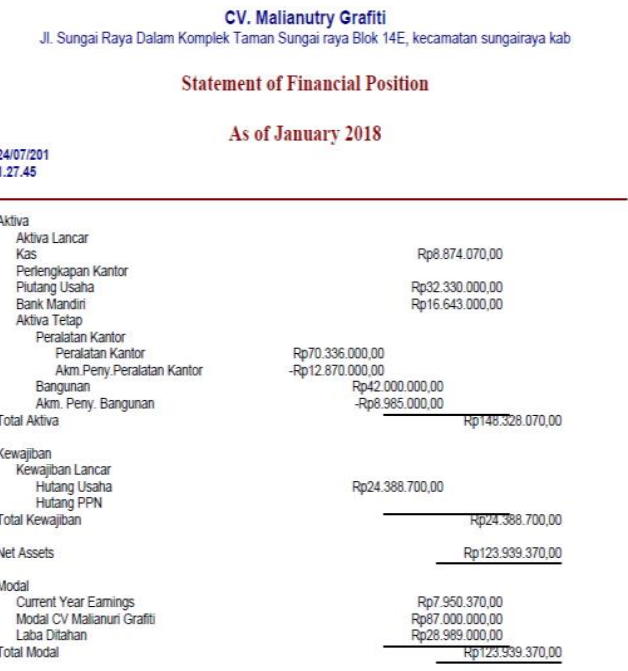

Sumber : Hasil Implementasi dengan MYOB Premier V.16

Gambar 17. Neraca

\subsection{Analisa Laporan Keuangan}


Analisa Laporan Keuangan adalah suatu proses penelitian laporan keuangan beserta unsur-unsurnya bertujuan untuk mengevaluasi hasil yang telah dicapai perusahaan. Analisis Rasio Keuangan merupkan suatu alat analisa yang digunakan oleh perusahaan untuk menilai kinerja keunangan berdasarkan data perbandingan masing-masing pos yang terdapat di laporan keuangan seperti Laporan Neraca dan Laba/Rugi pada periode tertentu.

Rasio Profitabilitas atau Rentabilitas Rasio untuk mengukur dan memberikan gambaran seberapa besar kemampuan perusahaan dapat meraih laba Dalam kaitannya dengan nilai penjualan, aktiva, maupun modal sendiri. Ada beberapa jenis rasio profitabilitas antara lain:

1. Gros profit Margin, untuk mengukur kemampuan perusahaan dalam mendapatkan laba kotor dari penjualan. Rumus menghitung gross profit margin:

2.

$$
\begin{aligned}
& \text { Gros Profit Margin }=\frac{\text { Laba kotor }}{\text { Penjualan bersih }} \times 100 \% \\
& \text { Gross Profit Margin }=\frac{\operatorname{Rp} 55.239 .250}{\operatorname{Rp} 68.866 .000} \times 100 \%=80 \%
\end{aligned}
$$

Dengan pengetahuan atas rasio ini dapat mengontrol pengeluaran untuk biayatetap atau biaya operasi lainnya, sehingga perusahaan dapat menikmati laba. Semakin besar rasio ini maka semakin baik.

$$
\begin{aligned}
& \text { Net Profit Margin }=\frac{\text { Laba kotor }}{\text { Penjualan bersih }} \times 100 \% \\
& \text { Net Profit Margin }=\frac{\operatorname{Rp} 7.950 .370}{\operatorname{Rp} 68.866 .000} \times 100 \%=11 \%
\end{aligned}
$$

Semakin besar persentasenya maka akan semakin baik, karna perusahaan dianggap mampu untuk mendapatkan laba yang cukup.

\section{KESIMPULAN}

Kesimpulan yang dapat diambil dari hasil penelitian ini adalah pemanfaatan aplikasi MYOB Premier V.16 dapat memberikan kontribusi dalam bidang keuangan berupa peningkatan hasil laporan keuangan sesuai dengan Standar Akuntansi Keuangan (SAK). Dan MYOB Premier V.16 ini dapat diimplementasikan pada perusahaan kecil, menengah maupun besar. Dengan kualitas laporan keuangan yang dihasilkan dari pengolahan transaksi dengan MYOB Premier V.16, laporan dapat menjadi bahan analisa keuangan yang akurat sehingga memudahkan dalam pengambilan keputusan.

\section{REFERENSI}

[1]. Mujiaty, Y., Irwin Ananta Vidada, Saridawati, Deasy Novayanti dan Ade Irwandi. (2019). Pengolahan Data Akuntasni Menggunkan Myob V16 Pada CV. Optik Bonie Jakarta Barat. 3, 1-9.

[2]. Rahmawati, Mari. (2015). Peran Aplikasi Komputer Berbasis Akuntansi untuk Badan Usaha dalam Perspektif Sistem Informasi. Perspektif, 13(2), 172-183. Diambil dari http://ejournal.bsi.ac.id/ejurnal/index.php/perspektif/article/view/921

[3]. Salim, Emil. (2019). Pengaruh Penerapan Penggunaan Software Akuntansi (Myob Accounting) Dalam upaya Mempermudah Dan Mengefisienkan Kinerja Pelaporan Keuangan Pada Perusahaan. 8(1), 92-101. 